\title{
UM ÓRFÃO NA EPIDEMIA - CONTO DE ELIYAHU MEIDANEK
}

\section{THE ORPHAN - A SHORT STORY BY ELIYAHU MEIDANEK}

Gabriel Steinberg*

Resumo: Este texto apresenta a tradução do conto $O$ órfão, do escritor em língua hebraica Eliyahu Meidanek.

Palavras-chave: Literatura judaica. Língua hebraica. Diáspora judaica.

Abstract: This text presents the translation of the short story The Orphan, by the Hebrew writer Eliyahu Meidanek.

Keywords: Jewish literature. Hebrew language. Jewish diaspora.

Eliyahu Meidanek nasceu na Ucrânia, parte do Império Russo, em 1882. Recebeu educação judaica tradicional enquanto demonstrava grande interesse pelos estudos seculares. A partir dos 13 anos, começou a escrever para o jornal judaico em língua russa Voskhod. Aos 17 anos, estabeleceu-se em Odessa, ${ }^{1}$ que concentrava uma parte considerável da intelectualidade judaica, onde entrou em contato com alguns renomados escritores, e foi especialmente influenciado pelo poeta Jeoshua Davidovich. Começou a publicar contos no jornal Haschiloah, publicação mensal em língua hebraica, criada por Ahad Ha'am em Odessa, em 1896. Profundamente abalado pelo pogrom de Kishnev ocorrido em 1903, cometeu suicídio em 22 de maio de 1904, aos 22 anos.

O conto aqui apresentado e traduzido diretamente do hebraico, foi publicado pela primeira vez em 1912, oito anos após a morte do escritor pela editora Tushiya, a inovadora casa editorial que existiu em Varsóvia, entre 1896 e 1914. Curiosamente, Meidanek nasceu na mesma época em que ocorreu a primeira aliá, a primeira onda imigratória de jovens judeus oriundos do Império Russo rumo à Terra de Israel, e morreu em 1904, ano em que se iniciou a $2^{\mathrm{a}}$ aliá, também motivada pela ocorrência de pogroms. Meidanek viveu numa época em que o movimento sionista estava tomando corpo e, também, o renascimento da língua hebraica. Essa tendência ficou documentada na publicação de vários periódicos em hebraico, em especial na Europa Oriental, e também no renascimento da língua hebraica falada na Terra de Israel.

Num período em que a língua estava se solidificando e novas palavras eram constantemente criadas, a narrativa de Meidanek flui sem grandes empecilhos. O conto tem, como personagem principal, um garoto que perdeu primeiro o pai, e posteriormente, também a mãe devido a uma epidemia. A narrativa delineia o sofrimento desse menino que, entre os sete e os oito anos de idade, teve de superar a dolorosa perda, até ser aceito no seio de uma nova

\footnotetext{
${ }^{*}$ Gabriel Steinberg é professor no Departamento de Letras Orientais da Faculdade de Filosofia, Letras e Ciências Humanas da Universidade de São Paulo. E-mail: <steinberg1818@usp.br>.

${ }^{1}$ Odessa - Cidade portuária ucraniana às margens do Mar Negro. No século XIX era a terceira cidade mais importante do Império Russo atrás apenas de Moscou e São Petersburgo. Os judeus se estabeleceram na cidade no século XIX quando esta se tornou um porto livre. Calcula-se que a população judaica somava mais de 160 mil pessoas no final do século, o que a tornou a maior cidade de população judaica do Império. Os judeus da cidade sofreram vários pogroms em 1881 e 1905. No final do século XIX, se consolidou na cidade o movimento do iluminismo judaico, e muitos judeus passaram a frequentar escolas e universidades e também foi fundada ali uma escola judaica moderna. Também nessa época foi criado um centro de apoio ao movimento sionista, e Odessa se transformou numa importante base de atuação do movimento nacionalista judaico. Foi ali que atuaram alguns dos grandes escritores sionistas e pioneiros da moderna literatura hebraica, entre eles Bialik e Klausner.
} 
família. No conto há também leves sinais da possível adesão do escritor ao projeto sionista que estava sendo engendrado.

O conto é eminentemente panfletário, pois é preciso entender o contexto histórico e social por trás da narrativa do autor. Confinados na chamada Área de Assentamento, entre os anos de 1791 e 1917, os judeus do Império Russo que englobava então partes da Polônia, Ucrânia, Bielorrússia e os países bálticos, eram constantemente perseguidos por determinações legais e pela violência física, usados pelo poder czarista como "bodes expiatórios", com o intuito de desviar a raiva do povo diante do poder imperial em fase de desmoronamento. No final do século XIX havia por volta de 4,5 milhões de judeus confinados nessa faixa de terra delimitada, de um lado, pelo Império Austro-Húngaro e, ao Leste, pela Rússia Czarista, eles perfaziam por volta de $10 \%$ da população dessa área. Nessa época, enquanto os judeus da Europa Central e Ocidental já vivenciavam um clima de emancipação e conquistavam direitos de igualdade, na Área de Assentamento, o poder czarista pretendia obrigar os judeus a se assimilarem à força à cultura eslava e, para isso, esse poder não media esforços em determinar suas ocupações econômicas, limitar o número de judeus que tinham acesso às universidades e impor uma série de restrições que, em definitivo, procuravam apagar a presença judaica naquela parte da Europa. É preciso lembrar também que os pogroms, os distúrbios antijudaicos ocorridos em 1881 e em 1903, contaram com o beneplácito e incentivo das autoridades governamentais.

Desta forma, o conto aqui apresentado, deve ser entendido como uma narrativa que tem esse pano de fundo histórico e social vivenciado na época pelos judeus. Trata-se, neste caso, de um conto que lida com os sofrimentos comuns a todas as pessoas, mas que, no caso dos judeus naquela época, torna-se uma metáfora da situação vivida por eles naquele período e naquele lugar, quando, estrangulados pelos confinamento geográfico e submetidos a constantes restrições e perseguições, tanto o socialismo que foi abraçado por uma parcela dos judeus quanto o sionismo surgiam como elementos redentores. Por coincidência, há no conto a narrativa de uma epidemia que dizima pessoas vulneráveis, assim como hoje são as pessoas dos grupos à margem os que compõem o maior número de vítimas da atual catástrofe.

\section{Um órfão na epidemia ${ }^{2}$}

\section{1}

Certa manhã, Jacob, um menino de seis anos, abriu os olhos. Os raios do sol penetraram pela janela do quarto, iluminando o belo e arredondado rosto do garoto, acordando-o. Jacob ficou muito feliz com a luz agradável, encantado por estar em seu leito macio, protegido pelo cobertor. Nesse momento, sua mãe colocava-se de pé à beira da cama. Um belo sorriso apareceu nos lábios do garoto ao ver sua amada mãe.

- Já acordou, meu filho? - Sua mãe chamou-o carinhosamente, aproximou-se e passou a mão macia sobre sua cabeça coberta por cachos pretos. - Você dormiu bem?

Jacob não respondeu, mas permaneceu deitado sob o cobertor. Ele continuou olhando para a mãe e seu rosto se iluminou de prazer. Nesse momento estava tudo muito bem com ele. Aquela foi uma manhã acolhedora que irradiava um calor tão agradável, e sua bondosa mãe, sua amada mãe estava ali com ele. Do que mais ele poderia sentir falta?

- Você já dormiu o suficiente, meu filho, e agora já é hora de levantar; papai está esperando por você na sala de jantar - disse-lhe a mãe suavemente.

\footnotetext{
${ }^{2}$ MEIDANEK, Eliyahu. O órfão. Proyect Ben Yehuda. Disponível em: 〈https://benyehuda.org /read/9370〉. Acesso em 01/03/2020.
} 
Jacob amava muito seu pai, que o esperava para o café da manhã. E ele, que acabara de acordar de uma confortável noite de sono, sentiu apenas coisas boas e agradáveis invadindo o seu ser. Quanto amor, alegria e prazer havia na sua vida! Que prazeroso mostrava-se aquele dia, e assim, certamente, seria o dia seguinte!

Jacob pulou da cama e beijou a mãe muitas vezes, e ela também o beijou amorosamente. Depois ele vestiu a roupa, lavou o rosto e as mãos. Então a mãe o pegou pela mão e o levou para a sala de jantar. O bule fumegante já estava sobre a mesa, e seu pai estava sentado em sua cadeira, lendo o jornal. Mas assim que Jacob apareceu no umbral da sala, o pai desviou os olhos do jornal e olhou para ele com amor.

- Olá filho querido! - disse-lhe carinhosamente - seu sono foi agradável?

Um riso alegre iluminou o rosto do pequeno Jacob. Ele aproximou-se do pai, beijou-o, e o pai também o beijou.

- Agora, meu filho, faça a oração da manhã - disse a mãe - Ela começou a ler diante dele, e ele respondeu com as seguintes palavras: "Sou grato a Ti, Rei vivo e eterno, por ter restaurado minha alma dentro de mim com misericórdia. Tua lealdade é grande. Abençoado seja Teu nome por toda a eternidade. "J" Jacob leu a oração em hebraico, e mesmo assim, ele a compreendeu perfeitamente, pois seu pai tinha the ensinado o significado de cada palavra desta oração. Ele agradeceu ao bondoso Deus que lhe deu a vida assim como a seus amados pais, e seu coração se encheu de amor e reverência ao grandioso e bondoso Deus.

Após a oração, Jacob sentou-se na cadeira à mesa, e sua mãe serviu-lhe um copo de leite quente. Ele bebeu o leite doce e começou a escutar a conversa dos pais a respeito das notícias que os dois liam no jornal. Jacob não entendia muito do que eles diziam, mas a voz de ambos conversando era muito envolvente.

- Que sábios que papai e mamãe são! - pensou ao observa-los. Ele terminou de beber o copo de leite, mas ainda permaneceu sentado, olhando para o pai e a para a mãe e ouvindo suas palavras. Mas quando o pai acabou de beber o chá, ele se levantou. Como já eram nove horas, ele teve que ir trabalhar na casa comercial, onde era o contabilista.

Jacob entristeceu-se quando viu o pai vestindo o casaco. Mas o pai virou-se para ele, o abraçou e o beijou.

- Eu preciso ir trabalhar agora, meu filho - disse ele com carinho. - Eu preciso trabalhar, meu querido. Quando você crescer, meu filho, você também trabalhará. Mas agora vá brincar com seus brinquedos e com sua mãe. Logo seus amigos virão e brincarás com eles. É muito bom que você brinque com eles. À tarde eu voltarei para casa e trarei para ti um belo presente! - E o pai saiu.

A mãe começou a arrumar os dormitórios, pois ela era zelosa com a limpeza e a ordem da casa, e Jacob começou a brincar com seus brinquedos. Jacob possuía muitos brinquedos: um cavalo e sobre ele um cavaleiro, um trenzinho, e muitos utensílios e outros objetos. Quando a mãe terminou os afazeres domésticos, sentou-se à mesa e se envolveu com a costura. Jacob trouxe os brinquedos e começou a brincar na frente da mãe. E de vez em quando, o som de sua risada suave e alegre tomava conta da casa. A mãe olhava para ele com amor, com o coração muito feliz ao ver seu lindo filho. Nesse momento, ela viu que ele estava conduzindo o cavalo pelo chão da sala e chamando por ele: Oh! Oh! tal como fazem os cocheiros quando chamam os cavalos, e brincando dessa maneira, ele ergueu o chicote e atingiu o cavalo uma e outra vez.

- O que você está fazendo, Jacob? - sua mãe chamou-o em advertência.

- Meu cavalo não quer correr, então eu bati nele com o chicote para que ele movimente as patas, - Jacob respondeu com uma risada.

- Quem te disse para fazer isso? - a mãe perguntou novamente.

- Vi os cocheiros fazendo isso com seus cavalos - respondeu Jacob.

\footnotetext{
${ }^{3}$ Trecho da oração da manhã que é feita imediatamente ao acordar.
} 
- Então, saiba meu filho, que somente pessoas más balançam um chicote contra um animal para bater nele - disse-lhe a mãe suavemente - Você acha que os cavalos não sentem dor quando batem neles? Você acredita que é certo causar dor a alguém?.

- É verdade, o cavalo também sente dor quando é espancado com o chicote, - repetiu Jacob enquanto estava levemente absorvido em seus pensamentos. Depois ele virou para sua mãe e disse:

- Me perdoe, mamãe, eu não vou mais bater no meu cavalo.

- Eu te perdoo, - disse a mãe - escuta sempre o que eu te digo e seja um bom garoto pois eu sempre te amarei.

- Eu sempre te ouvirei, mamãe, e você sempre me amará, - Jacob gritou alegremente, pegou a mão dela e a beijou muitas vezes. A mãe também o beijou, na testa. Jacob não voltou mais para os brinquedos, sentou-se na cadeira que ficava perto da janela, não muito longe do assento de sua mãe, e olhou para a rua observando tudo que lá acontecia.

- Olhe, minha mãe! Veja! - Jacob exclamou de repente. E sua mãe levantou-se e foi até a janela para ver o que estava acontecendo. Ela viu um ancião andando pela rua, suas roupas estavam rasgadas e gastas, e dos seus sapatos esfarrapados era possível ver os dedos dos pés. O velho andava encurvado, seu rosto estava muito magro e escuro.

- Por que esse velho está vestindo roupas tão rasgadas? - Jacob perguntou à mãe.

- Ele é um homem pobre, - respondeu a mãe, - ele não tem dinheiro para comprar roupas e sapatos novos.

- Ele não tem dinheiro? - Jacob ficou surpreso e após alguns instantes perguntou novamente:

- E de onde papai tira dinheiro?

- Papai trabalha e recebe salário por seu labor, o suficiente para nossas necessidades respondeu a mãe. - Deus dá a teu bondoso pai forças para trabalhar e ganhar o suficiente para nosso sustento.

- E esse homem velho? - Jacob voltou a perguntar.

- Esse velho? Ele é um homem fraco e doente, não tem forças para trabalhar, por isso ele precisa da ajuda de outras pessoas.

- E por que Deus não dá força a esse velho para que ele possa trabalhar? - o garoto voltou a perguntar.

- Por quê? - Sua mãe se deteve por um momento e disse: - O bom Deus cuida de todas as criaturas, mas Ele também deseja que nós sejamos bons e cuidemos uns dos outros. É por isso que Ele colocou no mundo pessoas que precisam da ajuda de outras pessoas, para que saibamos fazer o bem e ajudar os outros, e não apenas a nós mesmos.

- Sim? - o garoto exclamou. Ele olhou para a mãe com seus olhos negros demonstrando estar concentrado nos próprios pensamentos. $\mathrm{O}$ ancião continuou andando, aproximando-se cada vez mais da casa de Jacob.

- Mãe, aqui vem ele! - exclamou Jacob.

- Sim meu filho; em breve ele estará aqui.

- E o que faremos com ele? - perguntou Jacob.

- Nós lhe daremos algum dinheiro e também algo para comer, pois certamente, ele deve estar com fome.

- Esse velho está com fome? - Disse Jacob espantado. - E por que deixam que ele passe fome? E por que não o vestem com as mesmas roupas bonitas que papai usa? Não foi Deus que nos ordenou que devemos nos preocupar com os pobres e amá-los?

A mãe ouviu com atenção as perguntas inteligentes ficando feliz e orgulhosa de seu filho bondoso e sábio.

- Certamente, todo homem honesto deve ajudar os pobres em tudo o que for possível, disse Jacob. 
- Por favor, mamãe, me dê seu dinheiro e eu o darei a esse pobre homem.

Enquanto Jacob falava, o homem pobre abriu a porta da casa, chegou ao quarto onde Jacob e sua mãe estavam sentados e os cumprimentou numa voz baixa e triste. Jacob olhou para o homem com medo e certo espanto, mas após alguns instantes, se aproximou dele rapidamente, e sem dizer nada lhe entregou uma moeda que sua mãe lhe dera. O velho olhou para Jacob com gratidão e uma leve risada passou por seus lábios escuros.

- Bom garoto, bom garoto - disse em voz baixa e suave - Que Deus te abençoe e te dê uma vida longa, uma vida boa e feliz.

Jacob olhou alternadamente para o pobre e para a mãe, como se perguntasse o que fazer e, vendo que o rosto de sua mãe demonstrava alegria, ele também se viu alegre e reconfortado.

- Muito obrigado ao senhor, bom homem, por sua benção - disse a mãe ao velho. - Que Deus permita e meu filho cresça e se torne um homem bom e desejável a Deus e às pessoas. Agora, por favor, sente-se e coma.

O rosto do velho se iluminou com aquelas boas palavras, sentou-se, e ela lhe serviu um prato cheio de ensopado quente. O pobre homem comeu ansiosamente, enquanto o pequeno Jacob olhava admirado todos os movimentos daquelas mãos fracas e daqueles olhos úmidos e taciturnos. Quando o pobre homem terminou de comer, ele começou a falar com a mãe de Jacob, e lhe contou todas as suas aflições. Jacob ouviu suas palavras com atenção, embora não fosse capaz de compreendê-las.

$\mathrm{O}$ velho lhe disse que ele não tinha nenhum parente ou alguém que pudesse ajudá-lo naquela cidade; que sua única filha vivia numa cidade distante dali, e ela era muito pobre, e nessa cidade ele também tivera uma filha que ficara viúva, mas já havia morrido, deixando para trás um menino de sete anos e uma menina de doze. A menina trabalhava como empregada na casa de uma boa família que a ama e a tratava com piedade, por isso ela se sentia segura na casa. Ele também contou que, por sua vez, seu netinho também tinha sido acolhido na casa de uma boa família. E embora fossem pobres e tivessem mais filhos, eles amavam o pequeno órfão e o tratavam como se fosse um de seus filhos. Ao concluir seu relato, o velho acrescentou: "Que Deus seja bondoso com essas pessoas caridosas!".

- Meu neto é um garotinho pequeno - acrescentou o velho, - ele tem quase a idade de seu filho. Mas seu filho é um menino bonito e saudável. Que Deus o abençoe sempre e lhe dê uma longa vida. Já o meu neto é um menino fraco, debilitado e muito pálido.

Um suspiro pesado partiu do coração do velho ao falar essas coisas.

Pelas palavras do pobre homem, Jacob percebeu que ele estava muito amargurado, e seu coração doía por ele, e quando o ancião falou sobre seu neto, os olhos de Jacob encheram-se de lágrimas.

- Você tem um garotinho como eu? - perguntou Jacob ao pobre homem.

- Sim, meu filho - respondeu o homem - um garotinho como você, um pequeno e infeliz órfão.

- Órfão? - repetiu Jacob, e dirigindo-se a sua mãe perguntou: “O que é um órfão?"

- A mãe desse garoto morreu e seu pai também morreu, e agora ele é órfão sem pai e mãe, - disse-lhe sua mãe, embora fosse muito difícil para ela pronunciar essas palavras.

- A mãe e o pai dele morreram, ele não tem pai e mãe? - repetiu Jacob aquelas palavras com espanto. Ele compreendeu então que a tristeza desse pobre menino devia ser muito grande.

- Sim, sim, um órfão sem pai e sem mãe - repetiu o pobre homem a Jacob. - Ele não tem mais pais bondosos que o amem e se alegrem com ele, assim como sua mãe se alegra por você.

Jacob começou a chorar ao ouvir tais palavras, e os olhos de sua mãe ficaram cheios de lágrimas.

- Bom garoto, bom garoto é você, meu filho! - disse o homem a Jacob gentilmente, passando sua mão sobre seus lindos cachos. Jacob segurou sua mão e a beijou, depois ele caiu sobre o pescoço dela. 
- Mãe, mãe! implorou - peça a esse velho que nos traga seu neto, o órfão! Ele é um pobre garoto, ele não tem pai e nem mãe! Que ele o traga para nós, e você, mamãe, o amará, da mesma forma que você me ama, mamãe!

A mãe abraçou o filho e o beijou. O velho abaixou a cabeça e duas grandes lágrimas caíram de seus olhos sobre suas flácidas bochechas.

- Você é um garoto bondoso, - disse o pobre homem.

- Por favor, traga até aqui o seu neto - implorou Jacob - Vou amá-lo e brincar com ele. Eu tenho muitos brinquedos. Venha e lhe mostrarei meus brinquedos, - disse Jacob. Ele correu e trouxe seus brinquedos e os estendeu diante do ancião. Ao mesmo tempo, sua mãe também trouxe algumas roupas, entregou-as ao pobre homem, e ainda lhe deu um pouco de dinheiro. $\mathrm{O}$ velho agradeceu, abençoou-a, assim como ao filho e foi embora.

- Um irmão! - disse Jacob a sua mãe depois que o velho saiu - Ele trará para nós seu neto, e ele será meu irmão. Eu não tenho um irmão. E você será sua mãe amorosa sempre! - Ele voltou a abraçar sua mãe, e ela também o abraçou com carinho e o beijou.

Algum tempo depois, seus amigos vieram brincar com ele. Mas desta vez as crianças brincaram muito pouco, porque Jacob lhes contou sobre o menino órfão, que não tem pai e não tem mãe, e que virá brincar com ele, e ele, Jacob, o amará como a um irmão e lhe dará todos os seus brinquedos como presente. Sua mãe também o amará, pois ele não tem uma mãe que o ame. Jacob também lhes contou sobre o velho encurvado e seus olhos escuros, que não tem dinheiro para comprar uma roupa bonita, e nem sapatos, e que nem pão ele tem para comer.

Por muito tempo aquele sábio menino falou com seus amigos, que ouviram suas palavras com interesse e admiração. Esses meninos eram todos bons e felizes, nenhum deles sabia o que era a pobreza ou carecia de alguma coisa em seu lar. Todos eram amados pelos pais, e, por sua vez, amavam muito seus progenitores. Por isso ficaram surpresos ao ouvirem o relato de Jacob, seu amigo, e pela primeira vez, ficaram sabendo que existem pessoas famintas e que não tem o que vestir; e que existem crianças sem uma mãe bondosa que as abrace e as beije e lhes dê aquilo do qual sentem falta, além de lindos brinquedos, e então, eles se sentiram tão mal por aquelas crianças, crianças cujo destino era ruim e muito amargo.

Às 4 horas da tarde, o pai Jacob retornou da casa comercial, e Jacob correu em sua direção gargalhando:

- Pai, pai! - Chamou-o - um homem velho esteve hoje aqui, ele é um homem muito bom, muito pobre, e tem um garotinho como eu, um órfão.

Seu pai o beijou e o levou para a sala de jantar.

- Quem esteve aqui? - perguntou o pai à sua esposa.

Ela lhe contou sobre o pobre ancião e tudo o que Jacob dissera ao homem. Enquanto falava, ela olhou para seu amado filho, e o pai também olhou para ele com amor.

- Você fez bem, meu querido filho - disse ele. - Você deve amar as pessoas e fazer sempre o bem, e assim serás amado por Deus e por todos.

Jacob ficou feliz ao ouvir as palavras de seu pai, sentindo-se extremamente reconfortado.

- Meu amor por Deus e pelas pessoas será eterno, meu pai - disse Jacob.

Seu pai tirou do bolso um pequeno livro, deu-o a Jacob e disse:

- Eu prometi lhe trazer um presente, aqui está na sua frente.

- Um livro! - Jacob exclamou alegremente - Este livro é para mim? Não é, pai? Eu vejo que você e a mãe estão sempre lendo. A partir de hoje eu vou ler também! - Então ele abriu o livro e começou a folheá-lo. O livro estava cheio de imagens, imagens de animais e de vários utensílios, dos quais ele gostou muito.

- Vejam! - exclamou Jacob com alegria ao virar a primeira página, - vejam, aqui há um cachorro, igual ao cachorro que está em nosso quintal, e aqui um gato; olha mamãe, nosso gato 
está aqui no livro! - E Jacob continuou encontrando em seu livro imagens conhecidas, sentindose muito feliz com elas.

Mas quando chegou na terceira página, ele viu uma imagem estranha. Observou-a, virou para o pai e perguntou:

- Pai, qual é o nome deste animal?

- Se você quer saber o nome deste animal e o significado de todas as figuras do teu livro, você deve aprender, meu filho, leia os caracteres e as linhas que se encontram abaixo deles; então você saberá os nomes de todas as coisas que aparecem no livro. Você quer?

- Claro, claro que eu quero! - Jacob respondeu alegremente. Naquele dia, pela primeira vez, seu pai o instruiu a respeito da leitura e da escrita. A aula foi tão divertida que ele deixou de brincar com seus brinquedos por algumas horas.

2

Jacob viveu feliz junto a seus pais que o amavam e lhe ensinaram a perseguir o bem e a rejeitar o mal até completar os sete anos de idade. Mas, repentinamente, uma grande catástrofe o acometeu. E foi isto o que aconteceu. Num dia de outono, seu pai adoeceu. Jacob ficou muito triste ao ver o pai deitado o dia todo na cama, e ao perceber como sua mãe estava muito triste. $\mathrm{O}$ médico veio à casa deles, segurou a mão do pai por um longo tempo, inclinou-se contra a barriga e o peito e bateu com os dedos, depois escreveu algo num pedaço de papel. Logo recebeu o pagamento das mãos da mãe e deixou a casa. O pequeno Jacob estava temeroso. Seu tenro coração estava receoso de algo que ele não sabia prever o que era. Tremendo, Jacob aproximouse da cama do pai. Sua mãe estava sentada numa cadeira ao lado da cama. Repentinamente, os olhos de Jacob e de seu pai se encontraram. Seu pai queria sorrir para ele com carinho, mas ele não tinha forças para fazê-lo. Seus lábios se moveram num movimento estranho e sem demonstrar qualquer expressão. O pai queria levantar a cabeça apoiada no travesseiro e sentarse, mas ele não conseguia. Então ele estendeu a mão ao filho com dificuldade. Jacob a segurou e a beijou muitas vezes.

- Meu pai, meu pai - o menino exclamou tristemente - o que você tem, meu pai?

- Nada, filho - respondeu o pai em voz baixa e suave.

Jacob olhou para a mãe e viu lágrimas em seus olhos. Então ele caiu em seu colo e começou a chorar. Por alguns momentos a mãe o abraçou e deixou que as lágrimas escorressem de seus olhos; mas ela se recompôs, enxugou as lágrimas do rosto, dizendo a Jacob com amor e tristeza:

- Por que você está chorando, meu filho? Teu pai ficará bem, para de chorar, meu querido, pois não é bom que teu pai te escute chorar.

Jacob olhou para o pai por um instante e parou de chorar, mesmo com o coração apertado. Naquele dia, ele brincou apenas um pouco com seus amigos.

- Meu pai está doente e minha mãe está chorando - disse-lhes Jacob, e eles sentiram sua dor, e não puderam se alegrar e se divertir como faziam sempre. Também o livro Jacob não leu com sua mãe, como costumava fazer todos os dias.

Alguns dias se passaram, mas o pai de Jacob não se levantou mais da cama. O abandono tomou conta da casa, pois a mãe não se preocupava mais com a ordem nem com a limpeza, ela ficava dia e noite sentada junto à cama do doente. Jacob também estava muito triste. Ele ficou olhando para o pai, e depois para a mãe, e de repente começou a chorar amargamente. A mãe tentou consolá-lo e enxugou as lágrimas do seu rosto. A alegria que preenchera todos os espaços da casa até então se esvaiu; a voz de Jacob e sua risada alegre não eram mais ouvidos entre suas paredes. Com frequência, muitos de seus conhecidos vinham e sentavam-se junto à cama do 
pai e falavam com a mãe aos sussurros para não perturbar o descanso do doente. Eles também mostravam-se muito tristes. Jacob viu que a mãe estava conversando com as pessoas que visitavam a casa chorando, e ele também começou a chorar. Os parentes e conhecidos lhe trouxeram vários presentes, falaram com ele palavras bonitas e, nos últimos dias, também o levaram à casa deles, para que se divertisse com seus filhos e amigos. Mas Jacob foi com eles sem vontade, quase não brincou com seus amigos.

Um dia, a tristeza na casa aumentou ainda mais desde o início da doença do pai. O médico esteve no quarto do doente desde a manhã. Alguns dos parentes estiveram na casa o dia todo. Leah, uma parente da família que morava numa rua próxima, levou Jacob até sua casa, para brincar com seu filho Simon e com Tsila, a filha menor. Inicialmente, Jacob ficou triste e não participou dos jogos dos filhos de Leah; mas pouco a pouco, foi atraído pelos jogos, começou a brincar e quase se esqueceu do pesar, até que uma mulher veio e o levou de volta à família.

- Jacob, venha comigo pois seu pai quer vê-lo - disse a mulher. Jacob ficou muito feliz e disse: "Papai levantou da cama e mamãe não vai mais chorar?" Mas a mulher silenciou e não respondeu nada. O coração do garoto estava cheio de esperança e medo, e ele continuou andando com a mulher. Mas quando chegou em casa, ele ficou alarmado e silencioso. No quarto onde estava o pai, além da mãe e do médico havia ainda dois conhecidos, e um murmúrio silencioso tomava conta do lugar. Sua mãe estava muito pálida, de olhos vermelhos, sentada aflita na cadeira ao lado da cama do esposo. Jacob ficou imóvel de longe.

- Aproxime-se de seu pai, meu filho - disse a mãe com voz trêmula. Jacob olhou para o pai e ficou assustado. Sua aparência era terrível, seu rosto estava flácido e muito pálido, com os olhos afundados. Nesse momento, o pai virou a cabeça em direção ao filho e o encarou. Jacob apressou-se e aproximou-se de seu pai, colocou a mão dentro da palma fina e ressequida. Por alguns momentos, houve um profundo silêncio no quarto. Todos ficaram atentos ao encontro de Jacob e o pai.

- Jacob, meu filho - o pai começou a falar pesadamente e em voz baixa - eu estou morrendo. A mãe começou a soluçar baixinho, Jacob ficou assustado, de olhos muito abertos. O pai olhava alternadamente oras para a esposa, oras para o filho.

- Estou morrendo - disse o pai novamente ao filho - e você ficará órfão, sem pai... Ame muito a sua querida mãe. Ela será para ti pai e mãe. Ame a Deus com todo seu coração. Ele é um bom pai e misericordioso com os órfãos. Ame sua mãe, pois você será seu consolo na vida.

A mãe de Jacob começou a chorar copiosamente ao ouvir as palavras do esposo, mas Jacob não chorou, ouviu atentamente todas as palavras que o pai pronunciava. Depois de alguns momentos, o pai voltou a dizer:

- Você será um órfão, meu filho. Mas as pessoas boas não te abandonarão. Você se lembra de como demonstrou misericórdia com aquele menino órfão, o neto daquele ancião? Estude, meu filho, e seja feliz. Você é um hebreu!. Ame seu povo com todo seu coração, e com toda a sua alma. Agora você não pode entender minhas palavras, mas guarde-as em seu coração, não as esqueça. Você vai crescer, então entenderá. Cumpra meu último desejo e será abençoado.

O pai parou de falar, fechou os olhos e respirou pesadamente. Depois de alguns instantes, abriu-os de novo, olhou mais uma vez para sua esposa e para o filho, em seguida fechou-os novamente. Jacob olhou de modo atento o rosto do pai, e, súbito, começou a chorar compulsivamente. As pessoas que se encontravam no quarto o pegaram pelos braços levandoo a outro quarto, tentando acalmá-lo e confortá-lo. Mas Jacob continuou chorando sem prestar atenção às palavras de conforto. Ele sabia que logo não teria mais um pai. Logo, ele ficaria órfão. Leah levou-o novamente para sua casa e voltou a falar com ele e a reconfortá-lo, mas Jacob não quis ouvir, sentou-se em um dos cantos da sala e chorou de modo copioso. 
O sol se pôs e veio a noite. Jacob chorava o tempo todo até que ele não teve mais forças para chorar, ficou em silêncio num canto, absorto em seus pensamentos, sem olhar para tudo o que estava acontecendo ao seu redor, seu coração tenro doía muito. Leah aproximou-se dele e perguntou baixinho:

- Você não está com fome, meu querido? Por favor, meu filho, coma um pedaço de carne e um pouco de sopa. Por que você não joga com Simon e Tsila? Por que você está tão triste, meu filho? Por favor, vá brincar com Simon, meu querido!

Jacob, porém, não se levantou do lugar, não comeu a carne, tampouco provou o caldo que ela lhe servira, nem olhou para os brinquedos. De repente, elevou a voz e começou a chorar.

- Me levem para casa! Eu quero voltar para casa, para junto da minha mãe e do meu pai! Ele insistiu novamente, primeiro suplicando e logo depois começou a elevar sua voz.

- Está escuro agora lá fora, meu filho, a chuva está caindo forte. Temo sair agora - Leah falou suavemente com ele - E mais, para onde iríamos agora? Durma aqui esta noite, meu querido, por favor brinque com Simon e com a Tsila, amanhã de manhã iremos à sua casa. Sua mãe ficará feliz por você! Ela me pediu que esta noite você durma na minha casa. Esta noite você dormirá na mesma cama que Simon. Você gosta do Simon, não é? Vocês são meninos bons e bonitos. E você, Simon, meu filho, você quer dormir com Jacob?

Então Simon e a pequena Tsila, que até então olhavam para Jacob surpresos, se aproximaram dele, o encararam com seus bons e belos olhos, e disseram:

- Sim, mãe; eu realmente quero muito dormir com ele - respondeu o pequeno Simon à pergunta de sua mãe.

- Eu sabia que vocês três gostam um do outro - Leah dirigiu-se a Jacob com carinho - E por que não brincam juntos? Traga, Simon, meu filho, sua caixa de brinquedos e mostre-a a Jacob. E você, Jacob, vá brincar com Simon!

- Eu também brincarei com eles, minha mãe! - exclamou a menina com alegria.

Jacob olhou para as felizes crianças e parou de chorar. Simon e Tsila trouxeram todos os seus brinquedos: o cavalo com um soldado uniformizado montado, também um lindo carrinho, uma casinha com todos os utensílios dentro, bonecos e animais. Então montaram uma loja de brinquedos e cada um deles começou a exibir as mercadorias, e até simularam uma briga entre Simon e Tsila, sua irmã, em sua loja. Assim, Jacob pegou e apresentou os brinquedos, cada um de acordo com a utilidade e o valor. As crianças viram que ele se saíra bem e lhe permitiram que organizasse os brinquedos seguindo seu próprio critério. Jacob apresentou todos os brinquedos organizados em grupos, tal como tinha visto na loja de João, o vizinho de Leah. Simon era o comerciante, enquanto Tsila e Jacob eram os fregueses que compravam vários itens e os colocavam dentro de uma tigela quebrada. Leah olhou para o garoto com muito amor e piedade. Ela ficou feliz em ver que o menino, finalmente, passava a se concentrar no jogo.

Quando as crianças terminaram de brincar, Leah serviu a comida e, depois de comer, as levou até o dormitório fazendo-as deitar. Jacob deitou-se na mesma cama com Simon.

- Durmam, meus queridos filhos - disse-lhes Leah - Durma, meu querido - disse gentilmente a Jacob - Será muito bom dormir com Simon!

Simon abraçou Jacob e eles se deitaram.

- Nosso jogo foi muito divertido - disse a Jacob com prazer - amanhã jogaremos este jogo novamente.

Jacob também abraçou o amigo, e em alguns instantes os dois caíram no sono. Durante a noite um suspiro pesado rompeu de repente o sono de Jacob. Leah ficou observando as crianças, ouvindo o suspiro de Jacob, e um sentimento de compaixão, de muita pena a invadiu. De manhã Jacob acordou, vestiu-se, bebeu chá e sentou-se à mesa para o desjejum que Leah lhe servira. De repente, ele se levantou e disse com voz trêmula: "Quero ir para casa", e começou a chorar. 
- Não chore, meu filho - disse-lhe Leah com grande pena, os olhos cheios de lágrimas. - Logo iremos para sua casa, mas agora pare de chorar - e ela enxugou suas lágrimas.

No dia anterior ao noitecer, enquanto o menino estivera na casa de Leah, o pai de Jacob morreu e foi sepultado. O marido de Leah o acompanhou até o lugar do descanso eterno. Leah esteve naquela noite na casa de Jacob, permanecendo ao lado da cama da mãe dele, que desfaleceu quando o morto era retirado da casa. Depois de recobrar a consciência, ela permaneceu deitada atônita e em desespero, enquanto suas amigas a consolavam. De manhã, Leah vestiu Jacob com o casaco e o conduziu à casa de sua mãe.

- Não chore meu filho, não fique triste - Leah disse a ele enquanto estavam a caminho ame sua mãe, seja seu conforto na vida.

- Meu pai está morto? - Jacob perguntou com tristeza.

Leah reconheceu que Jacob percebia a tragédia que se abatera sobre sua família, mas ela não conseguiu responder-lhe nesse momento, pois estava muito aflita

- Pobre garoto! - exclamou com os olhos marejados - não sofra, meu filho, o bom Deus será para ti um pai misericordioso, Ele não deixará desamparados nem você nem a sua bondosa mãe.

Jacob chorou silenciosamente até chegar à casa com Leah. Ao entrar viu os quartos vazios e silenciosos. Sua mãe estava sentada triste e pálida em uma cadeira baixa, ouvindo as palavras de uma mulher ao seu lado. Quando ela viu o filho chegando, alegrou-se, e seu rosto iluminou-se por instantes. Jacob aproximou-se a passos largos e caiu no pescoço dela aos prantos.

- Minha mãe, minha mãe, minha mãe! - disse no alto de seu choro e agachado em sua direção, abraçou a mãe com força, temendo que ela também o abandonasse.

- Meu filho, meu filho querido! - disse ela ao abraçar sua cabeça e o beijou, suas lágrimas caíam sobre os lindos cachos do filho - você agora é órfão, meu filho, órfão de pai, mas Deus é o pai dos órfãos, Ele não te desamparará, sou grata a Deus que me deu um filho tão querido como você. Você será um consolo na minha vida.

- Mãe, minha mãe! Eu não tenho mais um pai! - exclamou Jacob chorando.

A mãe e o filho choraram juntos. A outra mulher também chorou com eles.

- Parem de chorar! - disse finalmente Leah, com grande amor e compaixão, seus olhos estavam cheios de lágrimas - vocês estão pecando contra Deus se continuarem chorando. Parem de chorar, meus queridos!

- Sim, por favor, meu filho, pare de chorar - disse-lhe a mãe, enxugando as lágrimas do garoto - o bom Deus cumpriu sua vontade. Não chore mais, meu filho!

- Eu não vou mais chorar, minha mãe - respondeu Jacob. Ele abraçou-a e a beijou muitas vezes, ela também o abraçou fortemente. Assim os dois permaneceram abraçados. Parecia que os corações da mãe e do filho estavam mais leves e ambos pararam de chorar.

Após a morte do esposo, a mãe de Jacob não quis voltar para à casa do pai dela, pois este tinha mais filhos e filhas que dependiam dele para o sustento. Ela também se recusou a aceitar ajuda financeira de conhecidos, então passou a ministrar aulas de etiqueta para moças, além de aulas de línguas. Os conhecidos enviaram-lhe as filhas com entusiasmo para que ela as instruísse, assim ela obteve dinheiro suficiente para o sustento do filho e suprir todas as necessidades. Após a morte do esposo, ela deixou a confortável residência onde morara por vários anos junto a seu amado esposo, alugando para si e para o filho uma pequena residência numa das ruas humildes onde o valor do aluguel não era elevado. Mesmo agora, nada faltava a Jacob na casa de sua mãe. Sua mãe encontrou conforto em seu filho após a morte do esposo. O 
amor pelo filho a fez esquecer a dor, e Jacob também encontrou forças junto à sua amada mãe, embora ele não voltasse a ser feliz e alegre como na época em que o pai estava vivo. Agora ele quase sempre ficava perto de sua bondosa mãe. Às vezes ela lhe ensinava a ler e a escrever, e às vezes ela brincava com ele. Frequentemente eles sentavam para conversar, e Jacob prendiase às agradáveis palavras ditas pela sua mãe. Ela lhe falava a respeito de seu falecido pai, cuja memória era muito cara a Jacob, e ele escutava esses relatos com atenção e respeito.

- Seu pai, meu filho, não morreu - disse uma vez ao filho. Ele a observou com seus olhos escuros, instigantes, e ouviu todos os pensamentos que eram pronunciados pela mãe - ele continua vivo, meu filho, ele se encontra agora num mundo onde reina o bem, ali sua alma vaga junto às almas de todas as pessoas bondosas que deixaram esta terra, sua alma paira e aprecia os prazeres divinos. Nesse mundo não há problemas nem mágoas, esse mundo é cheio de luz, bondade, amor e alegria sem fim. Para lá Deus nos conduz para que possamos sentir o bem, depois de termos vivido aqui na terra. Saiba meu filho, que os olhos de seu bondoso pai estão nos observando do alto o tempo todo, seu espírito estará sempre conosco. Portanto, meu filho, faça sempre o bem e tudo que era certo e correto aos olhos do seu pai. Ame sua mãe e a todos os seres humanos, seja diligente em seus estudos, pois esse era o maior desejo de seu bondoso pai enquanto ele viveu aqui conosco, então a alma de seu pai se alegrará por ti e te enviará bênçãos lá do alto, essa benção o acompanhará por toda a sua vida, e você será sempre feliz.

Frequentemente a mãe falava com ele nesses mesmos termos. O coração do menino enchia-se de respeito por Deus e por seu falecido pai, mais um profundo amor por sua mãe, o que o deixava bastante feliz.

- Eu sempre te amarei, minha mãe, sempre honrarei a memória do meu querido pai exclamou Jacob com fervor - sempre farei o que você me ensinou.

- Meu filho querido! - disse a mãe emocionada, ela o abraçou e o beijou, aproximando-o do peito; o rosto dele resplandeceu de felicidade sem fim. Sua vida agora era muito difícil, sua viuvez era um momento triste, seu bondoso e sábio filho era o único conforto e felicidade na vida. Foi assim que Jacob viveu com a mãe, uma vida cheia do amor materno. Mas os bons dias do garoto não durariam muito.

Cerca de seis meses após a morte do pai, um boato surpreendente e assustador se espalhou pela cidade: uma terrível doença contagiosa estava se alastrando por aquela terra. Não demorou muito e a devastadora epidemia eclodiu também na cidade onde moravam Jacob e sua mãe. As pessoas ricas e instruídas começaram a tomar cuidados em relação à comida e às bebidas e a manter a higiene tanto dentro como fora de casa, de forma muito mais intensa do que até então. Era sabido que a higiene e a cautela com os alimentos e as bebidas podiam proteger as pessoas de qualquer doença e dos vírus. Já os ignorantes diziam: - somente Deus nos preservará, a proteção não está em nossas mãos. - As pessoas que viviam em situação de pobreza e privação, habitando pequenos apartamentos insalubres, não se precaviam adequadamente de todas as causas prejudiciais à saúde humana, portanto, a doença espalhouse deixando muitas vítimas, precisamente no bairro onde residiam Jacob e sua mãe.

Naqueles dias, Jacob ficava sozinho em casa, porque sua mãe o impedia de sair com os amigos, nem os amigos vinham até ele. Um dia, enquanto Jacob estava sentado perto da janela, ouviu repentinamente um grito de choro oriundo do lado de fora. Ele olhou pela janela, eis que da casa em frente à casa deles, algumas pessoas retiravam um caixão preto e o colocaram numa carroça puxada por um cavalo. Era a carroça da funerária, e uma mulher com os filhos acompanharam o caixão aos gritos e com um choro amargurado. O garoto viu aquela imagem, teve medo. Sua mãe se encontrava na cama costurando uma nova túnica.

- Jacob - chamou-o - Por que você está olhando lá fora? Por favor, aproxime-se, meu filho, leia para mim uma página de seu livro. 
Jacob aproximou-se da mãe, sentou no colo dela e a beijou com muito amor, ela também o beijou na testa com olhos cheios de lágrimas. Jacob abriu seu livro e começou a ler uma bela lenda para sua mãe.

Um dia, a mãe de Jacob ficou muito agitada. De manhã, ela saiu para comprar as necessidades da casa e retornou triste, muito abatida. A visão das ruas desertas, as poucas pessoas que caminhavam pareciam sombras, seus rostos pálidos causavam um forte pavor da morte. Todas essas imagens lhe causaram uma impressão terrível. Ao chegar perto de sua casa, ela deu de cara com a carroça da funerária, que se apressava em conduzir um dos muitos que tinham deixado o mundo dos vivos. Essa visão foi aterrorizante e a deixou abalada. Uma ideia terrível passou por sua mente:

- E se eu também morrer? O que acontecerá com meu filho?

Instantes depois, ela esforçou-se para manter essa terrível ideia longe da mente e apressou-se para chegar em casa. Ela passou por uma das casas próximas da sua, quando ouviu um choro e um grito profundo que a fizeram deter-se. Ela viu então duas meninas chorando, uma parecia ter quinze anos, a outra, nove. As duas aproximaram-se e imploraram ajuda para acudir sua mãe, que adoecera repentinamente, ninguém em casa podia ajudá-la.

Sem pensar muito, ela seguiu as duas meninas e aproximou-se da mulher. Depois ela instruiu as meninas para que fossem chamar o médico. Enquanto isso, ela sentou-se junto à doente e procurou aliviar sua dor. Ela não atentou ao fato de que esta proximidade poderia acarretar o contágio pela terrível doença. A visão da infeliz mulher fez com que por um momento, ela se esquecesse de si mesma, passando a acudir a vizinha. Somente depois da chegada do médico e de seus auxiliares ela deixou a paciente e saiu de coração aliviado. Mas, ao chegar em casa, ela viu o filho alegre com sua chegada. Então foi tomada pelo pensamento assustador. Ela abraçou seu filho com força, beijou-o com muito amor e saudade, como se em breve, ela teria de se despedir dele para sempre. Desde esse dia ela não conseguiu mais ficar tranquila.

Alguns dias depois, enquanto estava sentada na cama e costurava, sentiu uma forte dor de cabeça e náuseas que a fizeram vomitar, então ficou temerosa. Ao se restabelecer ela disse: - foi um leve mal estar - retomando a seguir a costura. Quando viu que seu filho estava olhando pela janela, ela o chamou e pediu-lhe que ele lesse o livro na sua frente. Mas antes que pudesse concluir a leitura, ele olhou para sua mãe e ficou atemorizado ao ver seu rosto muito pálido.

- O que você tem, minha mãe? - perguntou assustado.

- Estou me sentindo muito mal, meu filho - disse ela em voz baixa - vá chamar a nossa vizinha.

Jacob saiu às pressas e chorando alto fez o que a mãe lhe ordenou. Quando os dois chegaram em casa, eles viram que a mãe estava de pé, vomitando, com a cabeça encostada na parede e seu corpo tremia. A vizinha enviou rapidamente Jacob para que chamasse marido dela. Depois de um tempo a casa ficou cheia de gente. Jacob foi levado por um dos homens até a casa de Leah, que ficou muito assustada ao ouvir o relato do homem, depois ela rapidamente tirou as roupas de Jacob, vestiu-o com as roupas de seu filho Simon. Antes disso ela jogou sobre ele uma água que possuía um odor muito desagradável. Jacob estava atônito e nada percebeu do que estava acontecendo. Ele ficou quieto e aflito sem dar atenção a Simon e Tsila que o encaravam silenciosamente.

Leah ordenou à criada que cuidasse das crianças, e correu para a casa de sua amiga. Chegando lá, ela encontrou alguns homens e mulheres e também dois médicos que estavam acudindo a doente. No entanto, nenhum remédio mostrou-se eficaz. A mãe de Jacob sentia muita dor e revirava-se na cama sem reconhecer ninguém nem saber o que estava acontecendo. Ela agonizou por cerca de seis horas até morrer. Instantes antes de sua morte, ela ficou um pouco mais leve ao se lembrar de Jacob, seu filho, e recobrando brevemente suas forças, perguntou sobre ele. Então Leah lhe disse que ele se encontrava em sua casa, prometendo adotá- 
lo como seu filho, educá-lo para ser um bom irmão para Simon e Tsila. Depois disso, ela elevou os olhos para o alto e seus lábios se moveram; parecia estar orando a Deus para que Ele fosse um pai misericordioso com seu desamparado filho, que logo ficaria órfão de pai e de mãe, e que Ele estendesse a bênção às boas pessoas que cuidariam de Jacob. Depois de alguns instantes, entregou o espírito a Deus.

Jacob não soube nada do que tinha acontecido com sua mãe, e quando Leah voltou para sua casa, depois que sua amiga fora sepultada, esforçou-se para esconder a tristeza dos olhos ao pequeno órfão e disse-lhe com amor e compaixão:

- Jacob querido, sua mãe ficou um pouco doente e voltou para a casa do pai; mas antes de ir me pediu que eu o trouxesse à minha, pois ela precisa ficar com o pai. Não deve se entristecer, meu querido, pois você ficará bem em minha casa. Fica conosco, você poderá brincar com Simon e com Tsila. Você é um garoto bom e inteligente, e eu e meu esposo o amaremos muito.

Jacob prestou atenção a suas palavras, e embora estivesse assustado e temeroso, acreditou firmemente nas palavras de Leah, mesmo tendo ficado surpreso com sua mãe, que repentinamente o deixou e viajou sozinha até a casa de seu pai.

- Foi assim que o pai dela quis, meu filho, e nós devemos fazer sempre o que nossos pais nos pedem - Leah continuou falando com ele - mas não fique triste, meu querido, você voltará a ver a sua bondosa mãe.

Jacob não entendeu o que ela estava tentando lhe dizer, ele simplesmente acreditou, pois nunca tinha ouvido mentira de ninguém. Ainda assim, ele ficou incomodado. À noite, quando foi deitar, não conseguiu dormir, ele só conseguia pensar em sua mãe, além disso começou a duvidar das palavras de Leah. Quando adormeceu, pareceu-lhe que sua mãe o estava procurando pelas ruas da cidade sem encontrá-lo. Então ele a viu chorando ao perguntar a todos os transeuntes se eles tinham visto Jacob, seu filho perdido. Uma outra noite, ele sonhou estar parado perto da janela, quando repentinamente um grupo de homens assustadores retiraram um caixão preto sobre os ombros em frente à casa de sua mãe, e, de repente, essas pessoas levaramna também, começaram a bater nela e a importuná-la, daí Jacob acordou chorando. Mas antes do amanhecer ele adormeceu e voltou a sonhar. No sonho, ele estava sentado em casa lendo o livro diante de sua mãe, quando de repente chegaram pessoas muito altas que usavam chapéus pretos, ele as reconheceu, eram os mesmos homens que vira pela janela retirando o caixão preto. Mas desta vez não teve medo deles, ele estava sentado calmamente ao lado de sua mãe. Os homens se aproximaram, eram cinco, eles traziam alguns brinquedos, um deles o chamou e lhe disse: "Venha comigo, eu lhe darei muitos mais ainda". Jacob olhou para a mãe e perguntou: "eu devo ir atrás deste homem?" E sua mãe lhe disse: "Vai, meu filho", então Jacob foi com o homem que o levou até uma casa. Jacob olhou em volta vendo que aquela era a casa de Leah. Ele olhou mais uma vez, mas desta vez percebeu que estava sozinho no quarto, olhou as paredes e os utensílios domésticos. Então ele viu de longe sua mãe na cama, quando chegaram os homens altos que usavam os chapéus pretos e atacaram sua mãe, agarraram-na pelos cabelos puxando-a de um lado para o outro. Diante daquela terrível visão, ele começou a tremer e quis correr em direção à mãe, mas não conseguiu dar um passo. Deu um enorme grito e acordou. Ele viu que Leah estava parada na sua frente olhando para ele com muita pena.

- O que aconteceu contigo, Jacob, por que você gritou? - Ela lhe perguntou.

- Quero ir ver minha mãe - disse o garoto angustiado, e começou a chorar.

- Não chore, querido, não chore - disse Leah, que com muito esforço segurou as lágrimas - sua mãe ainda não voltou da casa do pai, ela não está aqui - quando o pai dela pedir, nós todos 
iremos juntos para encontrá-la. Mas não podemos vê-la agora. Pare de chorar, meu querido! Jacob olhou para ela com seus grandes olhos, o rosto de Leah lhe transmitiu amor, compaixão, um grande pesar. Ele parou de chorar.

- Muito bem, muito bem, meu querido - disse Leah, vendo que ele havia parado de chorar. - Não chore mais, não é bom para um garoto esperto como você ficar chorando. Tente se animar, meu filho, veja como Simon está sempre feliz e alegre. Faça como ele, pois eu amarei os dois.

Jacob não respondeu nada, apenas olhou para ela e para Simon com tristeza. Leah o vestiu, lavou-lhe o rosto, as mãos e lhe deu de beber e comer. Jacob bebeu e comeu sem apetite, depois sentou-se no canto da sala pensando na mãe. O sonho que ele sonhara aquela noite não saía de sua cabeça. De repente um pensamento lhe ocorreu: ir a casa onde ele ficava com a mãe e ver o que estava acontecendo ali. Ele não disse a ninguém o que queria, pois tinha decidido fazer isso sem perguntar a Leah. Mas durante todo aquele dia, uma pesada chuva caiu do lado de fora. Leah permaneceu o tempo todo com as crianças. Jacob não conseguiu sair da casa e ficou muito triste o tempo todo. À noite, ele deitou na cama, sem conseguir dormir. As velas já tinham se apagado e todos os membros da casa dormiam. Ele ficou de olhos abertos - incapaz de dormir.

De repente, ocorreu-lhe fugir da casa e ir ver a casa de sua mãe. Levantou-se, começou a procurar as roupas, vestindo-as cuidadosamente, temeroso de acordar as outras crianças. Foi muito difícil fazer isso, porque o quarto estava escuro. Ao começar a andar, tropeçou numa caixa de ferramentas, um forte barulho se fez no quarto, mas mesmo assim as crianças não acordaram. Ele foi para a sala. Depois de tropeçar algumas vezes nas cadeiras, ele encontrou a porta e começou a procurar a fechadura, mas para seu azar, a porta estava fechada e trancada com a chave enfiada na fechadura. Ele tentou girar a chave na fechadura sem conseguir. Então segurou a chave com as duas mãos, reuniu todas as suas forças e girou a chave na outra direção. Desta vez a chave virou parecendo abrir a porta, porém ela ainda permanecia fechada. Com grande esforço, Jacob girou a chave mais duas vezes, mas a porta não abriu. Sua testa estava coberta de suor, as lágrimas escorriam, enquanto seu coração era invadido pela dor.

Por algum tempo, Jacob ficou parado diante da porta trancada, até que perdeu as esperanças de abri-la, e, por fim, decidiu voltar para o quarto. Mas devido à grande escuridão, ele não sabia como encontrar o caminho até sua cama. A casa toda estava num profundo silêncio, somente se ouviam os roncos dos membros da família. Jacob foi tomado pelo medo. Ele ia caminhando e apalpando as coisas à sua frente como um cego, caminhava e tropeçava nas cadeiras ou em outros objetos, sem encontrar a porta. O medo do menino cresceu muito, até que de repente, sem conseguir se conter, ele irrompeu num grande grito e seu choro acabou acordando a todos. Leah saiu do quarto e ficou surpresa ao ver Jacob chorando na escuridão da sala de jantar. A criada acendeu uma vela, e lá estava Jacob parado no meio da sala, vestido. Isso deixou todos ainda mais surpresos.

- O que aconteceu com você, Jacob? - perguntou Leah assustada - para onde você quer ir, meu filho?

Jacob parou de chorar, mas, assustado, não conseguia responder nada.

- O que acontece contigo, meu filho? - perguntou o esposo de Leah, que também acordou devido ao choro do menino - você precisa de alguma coisa? Por favor, me diga o que precisa e eu darei a você.

Jacob, porém, ficou em silêncio, não disse nada. Leah pegou-o e o levou para o quarto, deitou-o na cama e falou com ele calmamente tentando reconfortá-lo. Jacob começou a chorar novamente, a soluçar com clamor. Suas lágrimas caíram sobre o travesseiro e sobre o cobertor.

- Minha mãe! Oh, minha mãe, minha mãe - irrompeu num choro amargurado.

Leah sentou-se a seu lado e também derramou lágrimas por sua bondosa amiga e por seu infeliz filho órfão. 
- Olhe, meu filho - disse ela em lágrimas - aqui estão Simon e Tsila dormindo e você está chorando. Pare de chorar, meu querido, pois teu choro acabará por acordá-los. Você gosta de Simon e de Tsila, eles também amam você muito. E eu amo os três. Por favor, querido, deitese e durma!

Jacob parou de chorar e lentamente adormeceu. A mão de Leah permaneceu sob a cabeça dele. Quando Leah viu que ele tinha adormecido, ela lentamente tirou a mão e após um suspiro, levantou-se e voltou para seu quarto.

Quando amanheceu, Jacob demorou a acordar, mas ao se levantar, eram visíveis em seu rosto os traços das lágrimas que ele derramara à noite, os olhos estavam avermelhados. Ele permaneceu triste e absorto em pensamentos durante toda a manhã, e não prestou atenção em seu amigo Simon e nem em Tsila. Um único pensamento tomou conta dele: sair daquela casa e ir à casa de sua mãe. Muito ansioso, ele esperou por uma oportunidade de sair. Até o meio-dia ele não pode realizar esse desejo, pois todos os membros da casa estavam com ele. Mas, depois do almoço, o esposo de Leah foi trabalhar, e Leah foi ao mercado comprar o que precisava, deixando a criada, encarregada de cuidar das crianças. Quando, atarefada, a moça se deteve na cozinha, Jacob decidiu que havia chegado o momento oportuno para a saída. Dirigiu-se ao corredor. Simon viu que Jacob estava prestes a sair e disse:

- Eu também quero ir para o quintal, vamos juntos!

Jacob irrompeu em choro e disse-lhe em voz altar:

- Pare, eu quero ir sozinho!

Simon olhou para ele com espanto afastou-se e Jacob atravessou o corredor, dali encontrou a saída seguindo para a rua onde sua mãe morava. Ao sair, ele viu que as calçadas estavam cobertas de lama, o ar estava frio, um vento forte soprava do Leste, e nuvens carregadas flutuavam no céu. Caminhou um trecho e viu que o sol aparecia no Sul, mas sua luz não era agradável nem quente. Súbito o céu escureceu e gotas de chuva fria caíram na terra. Jacob a princípio caminhou devagar, mas, ao se afastar da casa de Leah, começou a apressar o passo e a correr. Ele passou por uma rua, atravessou a segunda, virou na terceira, até que por fim chegou à casa de sua mãe. Ele se deteve diante da casa e viu um monte de cal na frente da porta, o que o deixou confuso. Mas, olhando com cuidado, percebeu que aquela era mesmo sua casa, onde ele vivera com a mãe. Ele entrou e viu que todos os quartos estavam vazios. Uma fina camada de cal tinha sido derramada no chão, ele foi para o quarto onde sua mãe sempre permanecia sentada, mas esse quarto também estava vazio. Ele caiu no chão, começou a chorar e a gritar dizendo:

- Minha mãe, minha mãe! Onde está minha mãe!

As pessoas que passavam pela rua ouviram seu amargo grito e se aproximaram da casa, de corações partidos ao ver o pobre menino sentado no chão murmurando: "Minha mãe! Minha mãe"! - Alguns dos vizinhos que conheciam Jacob também apareceram.

- Pobre garoto! - disse um dos que estavam na casa - a mãe dele morreu e ele a chama pobre menino.

Jacó sentou-se no chão e chorando começou a suplicar:

- Onde está minha mãe? Por favor me digam, onde ela está? Para onde ela foi?

Nesse ínterim, Leah voltava do mercado. Quando chegou em casa, viu que Jacob não estava lá. Ela perguntou às crianças, que lhe disseram que ele havia saído. Então ela enviou a criada para que o procurasse no pátio, porém ela não o encontrou. Leah ficou temerosa, mas concluiu que Jacob poderia ter ido até a casa de sua mãe. Ela dirigiu-se até lá e encontrou Jacob sentado no chão, chorando amargamente. Ela o pegou e o levou de volta.

Desde aquele dia em diante, o menino ficou abatido. Ele não prestou mais atenção nos amigos nem nos jogos, nem em Leah, nem em seu esposo, tampouco às suas palavras. Ele parecia não entender o que eles diziam para reconfortá-lo, permanecendo sempre triste e silencioso. Leah e o marido ficaram muito tristes, até consultaram os médicos, mas nem estes 
conseguiram encontrar uma solução. Com frequência o menino sentava num dos cantos da casa, ficando ali imóvel por muitas horas, absorto, sua alma parecia estar mergulhando no abismo. Ele permaneceu pensativo o tempo todo concentrado em sua mãe, cuja lembrança não o abandonava sequer por um momento. Até a lembrança do pai tomou conta dele. Um dia, enquanto permanecia silencioso, as lembranças começaram a invadir sua memória. Ele viu o quarto no qual estava o médico e várias outras pessoas sentadas, também a cama na qual o pai ficara deitado com o rosto magro e os olhos afundados, mas o lugar de sua mãe estava vazio. Então ele pensou:

- Onde está mamãe? Para onde ela foi? Para onde desapareceu?

Essa pergunta o afligiu longamente, sem, no entanto, encontrar uma resposta. Por muito tempo continuou tentando achar uma explicação, mas sua dor apenas aumentava. Devagar, todas as visões e memórias se perdiam deixando-lhe a mente vazia. Mas ele sentia o coração apertado, tentava apagar as memórias, em vão. Assim permaneceu sentado por várias horas sem poder se acalmar.

Um dia, como vinha fazendo, Jacob estava sentado no chão do quarto desolado. De repente ele olhou para cima e viu um casaco azul claro que estava sobre a cama, e o reconheceu. Era o mesmo casaco que ele usara no inverno passado, tinha um cinto de couro, lembrou-se de que sua mãe o tinha costurado, dando-lhe como presente de aniversário no dia em que ele completara sete anos. Ele se lembrou daquela noite, quando seus amigos foram até ele e sua mãe e lhes deram doces, nozes, maçãs. Ele se lembrou do rosto de sua mãe, expressando satisfação e um amor sem fim. Mas ele viu também o rosto de seu bondoso pai, bonito, porém pálido, com sua pequena barba negra que lhe cobria as bochechas, sua testa alta e branca, seus olhos negros que expressavam sabedoria e bondade. Essas memórias despertaram nele alegria e saudades por aquelas pessoas tão amadas. Ele se lembrou que essas pessoas amadas estavam perdidas, não existiam mais, o que o deixou muito triste, inundado de lágrimas. Ele chorava pela primeira vez depois de ter visitado a casa onde vivera com a mãe.

Naquele momento, Simon entrou no quarto e viu que Jacob estava chorando, então ele correu até sua mãe e contou a ela o que vira. Leah apressou-se até o quarto e encontrou Jacob chorando baixinho, lamentando: "Minha mãe! Minha mãe!" Ela não conseguiu se conter, começou a chorar também.

- Jacob, meu querido, por que você está chorando? - ela lhe perguntou com grande afeto. Jacob levantou os olhos marejados, perguntou:

- Minha mãe está morta?

Leah não conseguiu responder, estava muito aflita. Mas então ela acabou reconhecendo que a alma de Jacob estava curada e suas lágrimas haviam acalmado seu espírito, aliviado sua profunda angústia. Ela começou a confortar e a consolar Jacob com palavras boas, reconfortantes, que saíam do seu bondoso coração cheio de amor e compaixão. Essas palavras eram semelhantes às palavras de sua mãe. Ele continuou chorando, mas sentiu o coração aliviado.

Embora Deus tenha levado seu pai e sua mãe - disse-lhe Leah - eles estão agora no mundo superior, e certamente lá é sete vezes melhor do que viver aqui na terra. Um dia virá, meu filho, e você também chegará a esse mundo bom, vocês estarão novamente juntos e nunca mais se separarão. Agora seja forte, meu filho. O bom Deus lhe deu vida, você tem a obrigação de viver. Ele tirou de ti os teus pais, mas ele encheu de compaixão o coração de outras pessoas que te amam de todo o coração como se você fosse filho deles. Sim meu filho, você não é um órfão abandonado pelo mundo, você tem agora bons pais e irmãos que te amam. É certo que conheceu o sofrimento dos órfãos, mas agora você será amado. Portanto, seja um filho atento, um garoto esperto e bom, e eu e meu esposo seremos bons pais para ti e nossos filhos serão bons irmãos. 
Foi assim que Leah falou, e Jacob entendeu todas as palavras agradáveis e certas que ela dizia. Com o coração refeito ele sentiu que não era um órfão abandonado, existiam pessoas amorosas que se importavam muito com ele, então sentiu-se aliviado e parou de chorar.

- Embora as almas dos meus pais estejam sempre vivas ao meu lado - disse Jacob depois que parou de chorar - eu devo fazer sempre o que meu pai e minha mãe me ordenaram enquanto estavam vivos? Não é?

- Sim, sim, meu querido - disse Leah, que ficou muito emocionada ao ouvir palavras tão sensatas saindo da boca de um garotinho, enquanto as lágrimas escorriam de seus olhos, lágrimas de compaixão e amor por esse menino sábio de alma pura e inocente.

Daquele dia em diante, Jacob mudou. Embora o sofrimento estivesse em seu rosto o tempo todo, ele passou a brincar com seus amigos que estavam felizes por ele, tornando-se um rapaz sábio e bondoso, que amava Simon e Tsila como seus irmãos, e Leah e seu esposo como bons pais. Todos eles também tinham por ele um grande afeto. Leah contratou um professor para ele e Simon, e Jacob concentrou-se em seus estudos com toda a paixão. Seu professor era um homem muito inteligente e, vendo que Jacob tinha bom coração, grande capacidade de compreensão, passou a contar a ele histórias agradáveis sobre o povo de Israel e sua terra sagrada, para a qual todo filho de Israel deve elevar seu coração. Jacob ouviu atentamente todos os relatos do professor. Naquele momento, parecia-lhe que seu falecido pai estava dizendo a ele todas essas agradáveis palavras, e o coração encheu-se de amor pelo seu povo e por sua terra, a Terra de Israel. 